\title{
Pharmacological characterization in vitro of prostanoid receptors in the myometrium of nonpregnant ewes
}

\author{
D. J. Crankshaw and V. Gaspar \\ Department of Obstetrics and Gynecology, McMaster University Health Sciences Centre, \\ 1200 Main Street West, Hamilton, Ontario, Canada L8N 3Z5
}

\begin{abstract}
Prostanoid receptors regulating the contractility of strips of myometrium obtained from nonpregnant ewes during the breeding season were classified pharmacologically. Natural prostanoids, receptor-type selective synthetic analogues, and selective antagonists were used where available. The natural prostanoids $\mathrm{PGD}_{2}, \mathrm{PGE}_{2}$, and $\mathrm{PGF}_{2 a}$ were equipotent in causing contractions ( $\mathrm{pD}$, values of $6.9,6.7$, and 6.9 , respectively) but were 100 times less potent than oxytocin $\left(p \mathrm{D}_{2}=9.2\right)$. The synthetic prostanoids iloprost $\left(p \mathrm{D}_{2}=8.3\right), \mathrm{GR} 63799 \mathrm{x}$ $\left(p \mathrm{D}_{2}=7.0\right)$, cloprostenol $\left(p \mathrm{D}_{2}=6.8\right)$, and $\mathrm{U} 46619\left(p \mathrm{D}_{2}=6.2\right)$ also caused contractions. The effects of iloprost, but not of GR63799x, were blocked by the selective $\mathrm{EP}_{1}$ antagonist AH6809. This suggests the presence of both $\mathrm{EP}_{1}$ and $\mathrm{EP}_{3}$ receptors. The similar potencies of cloprostenol and $\mathrm{PGF}_{2 \alpha}$ suggest the presence of FP receptors. Although the potency of the TP agonist U46619 was relatively low, its effects were blocked by the selective TP antagonist L670596 ( $p \mathrm{~K}_{\mathrm{B}}=8.4$ ), an observation consistent with the presence of TP receptors. Thus, all currently recognized excitatory prostanoid receptors $\left(\mathrm{EP}_{1}, \mathrm{EP}_{3}, \mathrm{FP}\right.$ and $\left.\mathrm{TP}\right)$ appeared to be present. Contractions induced by cloprostenol and $\mathrm{KCl}$ could be inhibited by the $\beta$-adrenoceptor agonist isoprenaline ( $\mathrm{DD}_{2}=8.8$ against cloprostenol) and the $\mathrm{Ca}^{2+}$-channel blocker, D600 ( $p \mathrm{D}_{2}=6.3$ against cloprostenol), but a number of relaxant prostanoids, BW245c, ZK110841, AH13205 and cicaprost, could not produce inhibition. These results suggest that $\mathrm{DP}, \mathrm{EP}_{2}$ and IP receptors do not regulate contractility under these conditions.
\end{abstract}

\section{Introduction}

Novy and Liggins (1980) suggest that prostanoids play a physiological role in the regulation of uterine activity in a number of species. In ewes, work aimed at delineating this role has focused, almost exclusively, on alterations in prostanoid concentrations in various compartments during different phases of the reproductive cycle (Olson et al., 1986). Scant attention has been paid to the actions of these compounds at the putative end-organ.

In humans (Senior et al., 1991, 1992, 1993), the direct effects of prostanoids on uterine contractility are mediated through actions at seven different receptors, some of which are excitatory, others inhibitory. In ewes, however, the prostanoid receptor status of the myometrium is not known.

In the present study, the prostanoid receptor status of the myometrium of nonpregnant ewes during the breeding season was determined pharmacologically by studying the effects of prostanoid receptor-selective analogues on the contractility of the myometrium in vitro.

\section{Materials and Methods}

\section{Collection of myometrium}

Reproductive tracts were obtained from two abattoirs in the vicinity of Hamilton, Ontario $\left(43^{\circ} 15^{\prime} \mathrm{N}\right)$. They were collected

Received 25 July 1994. between 15 September and 15 December over three successive seasons, from crossbred yearling ewes or ewe lambs weighing more than $40 \mathrm{~kg}$. The tracts were placed in ice cold physiological salt solution (PSS) of the following composition $\left(\mathrm{mmol}^{-1}\right.$ ): potassium chloride 4.6 , magnesium sulfate 1.16 , sodium dihydrogen phosphate 1.16, calcium chloride 2.5 , sodium chloride 115.5, sodium bicarbonate 21.9 and glucose 11.1 with indomethacin at $10 \mu \mathrm{mol}^{-1}$, and transported to the laboratory. In the laboratory, the ovaries were inspected for indications of reproductive status. Only uteri from animals with an active corpus luteum, or large fluid-filled follicles accompanied by a recently regressed corpus luteum in at least one ovary, were included in the study. Results from uteri from 45 animals that met these criteria are reported. None of these reproductive tracts showed any indication of trophoblastic activation. The uteri were washed with oxygenated $\left(95 \% \mathrm{O}_{2}: 5 \% \mathrm{CO}_{2}\right)$ PSS at room temperature, cleared of any adhering fat and connective tissue, and eight longitudinal strips of myometrium approximately $1.5 \mathrm{~cm}$ in length and $0.04 \mathrm{~cm}^{2}$ in cross-sectional area were cut from the body of the uterus.

\section{Recording of isometric contractions}

General protocol. Tissue strips were tied at each end with silk thread and mounted longitudinally in individual $10 \mathrm{ml}$ jacketed muscle baths containing oxygenated PSS at $37^{\circ} \mathrm{C}$. One end of each strip was anchored in the bath; the other was 
Table 1. Composition, concentration and sources of compounds used

\begin{tabular}{|c|c|c|}
\hline Compound & Stock solution & Source \\
\hline 17-phenyl trinor $\mathrm{PGE}_{2}$ & $10^{-3} \mathrm{~g} \mathrm{ml}^{-1}$ in absolute ethanol & Cayman Chemical, Ann Arbor, MI \\
\hline AH13205 & $10^{-2} \mathrm{~g} \mathrm{ml}^{-1}$ in $1 \%(\mathrm{w} / \mathrm{v}) \mathrm{NaHCO}_{3}$ & Glaxo Group Research \\
\hline BW245c & $10^{-2} \mathrm{~mol} \mathrm{l} l^{-1}$ in absolute ethanol & Wellcome Research Laboratories, Beckenham \\
\hline BW A868c & $10^{-2} \mathrm{~mol} \mathrm{l}^{-1}$ in absolute ethanol & Wellcome Research Laboratories \\
\hline Cicaprost & $5 \times 10^{-5} \mathrm{~g} \mathrm{ml}^{-1}$ in aqueous solution & Schering AG, Berlin \\
\hline D600 & $10^{-3} \mathrm{~mol} \mathrm{l}^{-1}$ in $0.9 \%(\mathrm{w} / \mathrm{v})$ saline & Sigma Chemical Co. \\
\hline GR63799x & $10^{-2} \mathrm{~g} \mathrm{ml}^{-1}$ in absolute ethanol & Glaxo Group Research \\
\hline Iloprost & $10^{-5} \mathrm{~g} \mathrm{ml}^{-1}$ in aqueous solution & Schering $A G$ \\
\hline Indomethacin & $5 \times 10^{-3} \mathrm{~mol} \mathrm{I}^{-1} \mathrm{Na}_{2} \mathrm{CO}_{3}$ & Sigma \\
\hline Isoprenaline & $\begin{array}{l}10^{-2} \text { mol l } \\
\text { ascorbate }\end{array}$ & Sigma \\
\hline Oxytocin & $10^{-3} \mathrm{~mol} \mathrm{l}^{-1}$ in $0.9 \%(\mathrm{w} / \mathrm{v})$ saline & Vega, Tucson, AZ \\
\hline $\mathrm{PGD}_{2}$ & $10^{-2} \mathrm{~mol} \mathrm{l}^{-1}$ in absolute ethanol & Cayman Chemical \\
\hline $\mathrm{PGE}_{2}^{2}$ & $10^{-2} \mathrm{~mol} \mathrm{l}^{-1}$ in absolute ethanol & Cayman Chemical \\
\hline $\mathrm{PGF}_{2 a}$ tromethamine salt & $10^{-2} \mathrm{~mol} 1^{-1}$ in $0.9 \%(\mathrm{w} / \mathrm{v})$ saline & Cayman Chemical \\
\hline Sulprostone & $10^{-3} \mathrm{~g} \mathrm{ml}^{-1}$ in aqueous solution & Schering AG \\
\hline U46619 & $10^{-2} \mathrm{~g} \mathrm{ml}^{-1}$ in methyl acetate & Cayman Chemical \\
\hline ZK110841 & $1.25 \times 10^{-3} \mathrm{~g} \mathrm{ml}^{-1}$ in absolute ethanol & Schering AG \\
\hline
\end{tabular}

attached to an FT-03 force displacement transducer writing to a 7D polygraph (Grass Instruments, Quincy, MA). An initial resting force of $40 \mathrm{mN}$ was applied to each tissue. This usually declined rapidly and was readjusted throughout the next hour to obtain a steady baseline force of $25 \mathrm{mN}$. Throughout this period, the bath solution was changed regularly. Tissues were then challenged with potassium chloride $\left(90 \mathrm{mmol}^{-1}\right)$. Any strip that failed to develop force in response to this challenge was discarded. Potassium chloride was washed from the bath and tissues were allowed to equilibrate for a further hour. The mean force developed by the individual muscle strips during $10 \mathrm{~min}$ was used as a measure of their contractility. This technique has been used routinely in this laboratory (Dyal and Crankshaw, 1988; Wainman et al., 1988) and others (Cheuk et al., 1993), since it can be used to quantify drug effects in tissues that develop significant spontaneous activity and respond to stimulation by changes in both tonic and phasic activity (Crankshaw, 1990). Mean force was determined exactly as described by Wainman et al. (1988).

\section{Concentration-effect curves to excitatory agonists}

At the end of the equilibration period, the mean force developed during a $10 \mathrm{~min}$ control period was determined. Drugs were then added to the baths, in a cumulative fashion, by increments that would produce approximately one half log unit changes in the concentration in the bath. After each addition, the mean contractile force was determined for $10 \mathrm{~min}$. The mean force recorded in $10 \mathrm{~min}$ immediately after agonist addition minus the mean control force was considered to be the force developed in response to that concentration of agonist. Additions were continued until further addition produced no further increase in developed force. Concentration-effect curves (response versus log molar agonist concentration) were then constructed from these data by fitting the equation

$$
E=E_{\text {min }}+\left(\mathrm{E}_{\text {max }}-\mathrm{E}_{\text {min }}\right) / 1+\mathrm{e}^{-\mathrm{k}(\log C-\log D)}
$$

where $E$ is the effect of the agonist, $C$ is the molar concentration of the agonist and $D$ is the molar concentration of the agonist that produces a half maximal response $\left(E C_{50}\right)$. The value of $-\log D$ is equivalent to the negative $\log _{10}$ of the molar concentration of the agonist that produces $50 \%$ of the maximal response, $p \mathrm{D}_{2}$ values.

Normally the same agonist was tested on two muscle strips from the same animal and the average of the two $p \mathrm{D}_{2}$ values obtained was used. Thus $n$ values represent the number of animals on which each drug was tested.

\section{Concentration-effect curves to inhibitory agonists}

Although most tissues developed spontaneous contractile activity during the equilibration period, this activity decayed with a time course that was highly variable, particularly between animals, but also between strips from the same animal. This made it difficult to obtain concentration-effect data for inhibitors. To remedy this problem, strips were stimulated in two different ways, and the effect of drugs on this stimulated activity was examined. At the end of the equilibration period, the PSS was changed to a solution that contained either $40 \mathrm{mmol}$ potassium chloride $\mathrm{I}^{-1}$ or $2 \mu \mathrm{mol}$ cloprostenol $\mathrm{l}^{-1}$. 


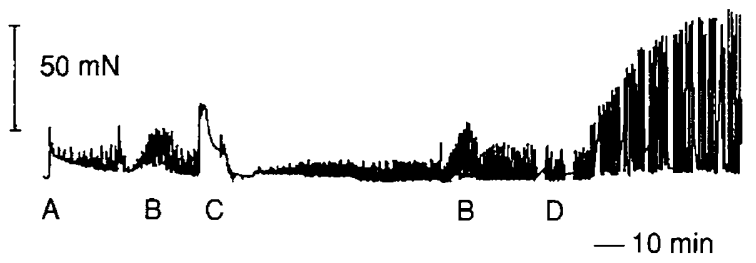

Fig. 1. The effect of the EP receptor agonist, GR63799x, on the contractility of the sheep myometrium in vitro. Record of force development during the experiment showing the manual setting of initial tensions and immediate development of high frequency, low amplitude contractions (A), the development of low frequency, high amplitude contractions (B), a contraction induced by $\mathrm{KCl}(\mathrm{C})$ and the concentration effect in the experiment (D).

Strips were left for $1 \mathrm{~h}$ before concentration-effect experiments were begun. Procedures for these experiments were similar to those for excitatory agonists, except that two strips out of every eight were used as time-matched controls, and the response was a decrease in contractile activity. At the end of the experiment, the L-type calcium channel blocker D600 was added to each tissue bath at a final concentration of $100 \mu \mathrm{mol}$ $\mathrm{I}^{-1}$. After exposure to D600 for $15 \mathrm{~min}$, a final data collection was performed. We expected D600 to reduce activity to a basal tone and therefore used this maximal D600 response to define zero contractility. The zero contractility value was subtracted from all preceding values, which were then expressed as a percentage of the control values. Drug effects were then calculated according to the following equation:

$$
E_{x}=\left(\left(D_{x}-C_{x}\right) /-C_{x}\right) \times 100
$$

where $E_{x}$ is the percentage inhibition produced by the drug at concentration $x, D_{x}$ is the percentage of control period activity developed in the presence of concentration $x$ of the drug, and $C_{x}$ is the percentage of control period activity developed in the time-matched control tissues for the same period.

\section{Effects of antagonists}

In attempts to delineate the site of action of a number of excitatory agonists, experiments were performed to investigate the effects of selective receptor antagonists on their action. The general protocol as described above was used, except that four tissue strips from each animal were used. Two tissues were incubated in the presence and two in the absence of the specified antagonist for $1 \mathrm{~h}$ before control data were obtained, and throughout the course of the concentration-effect experiment. The $p \mathrm{D}_{2}$ values obtained in the presence of antagonist were compared with those obtained in its absence. Where appropriate, $p \mathrm{~K}_{\mathrm{B}}$ (negative $\log _{10}$ of the molar concentration of antagonist that would occupy $50 \%$ of the receptors in the absence of agonist) values for the antagonists were calculated using the Gaddum equation:

$p \mathrm{~K}_{\mathrm{B}}=\log ($ concentration ratio -1$)-\log$ (antagonist concentration)

Where concentration ratio $=E C_{50}$ value in the presence of antagonist: $E C_{50}$ value in the absence of antagonist.

\section{Drugs}

The compounds used in this study, the composition and concentration of stock solutions, and the source of the compounds are all listed in Table 1. Dilutions from stock solutions were made on the day of the experiment directly into saline and were kept on ice for the duration of the experiment. Stock solutions were maintained as recommended by the suppliers, except for carbachol, isoprenaline and sulprostone which were made up freshly for each experiment, and indomethacin which was treated according to the method of Curry et al. (1982). The aqueous solutions for iloprost and cicaprost were as supplied by the manufacturer. All other chemicals were from $\mathrm{BDH}$ (Toronto).

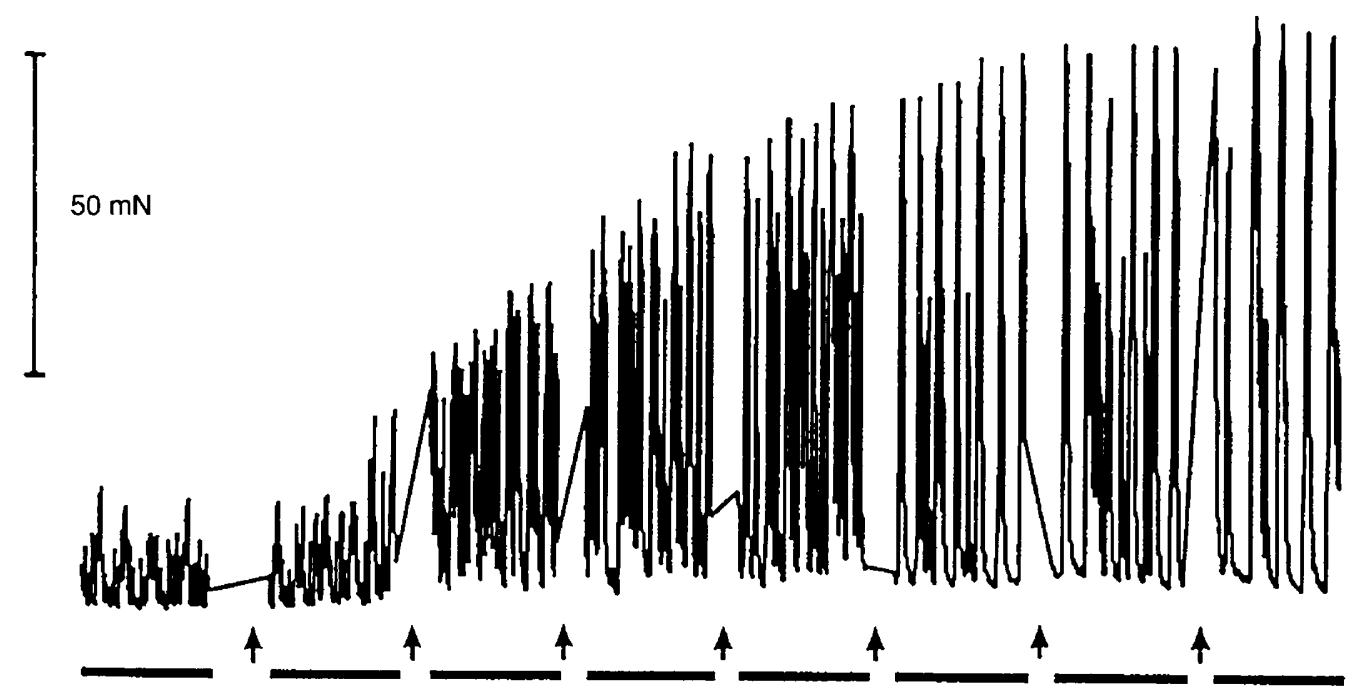

Fig. 2. Detail of Fig. I showing the concentration effect experiment. Horizontal bars indicate data collection for $10 \mathrm{~min}$, the first of which is the control. Thereafter, the EP receptor agonist, GR63799x, was added cumulatively at the arrows to give concentrations in the bath ranging from $1 \mathrm{nmol} 1^{-1}$ to $1.4 \mu \mathrm{mol} l^{-1}$. 


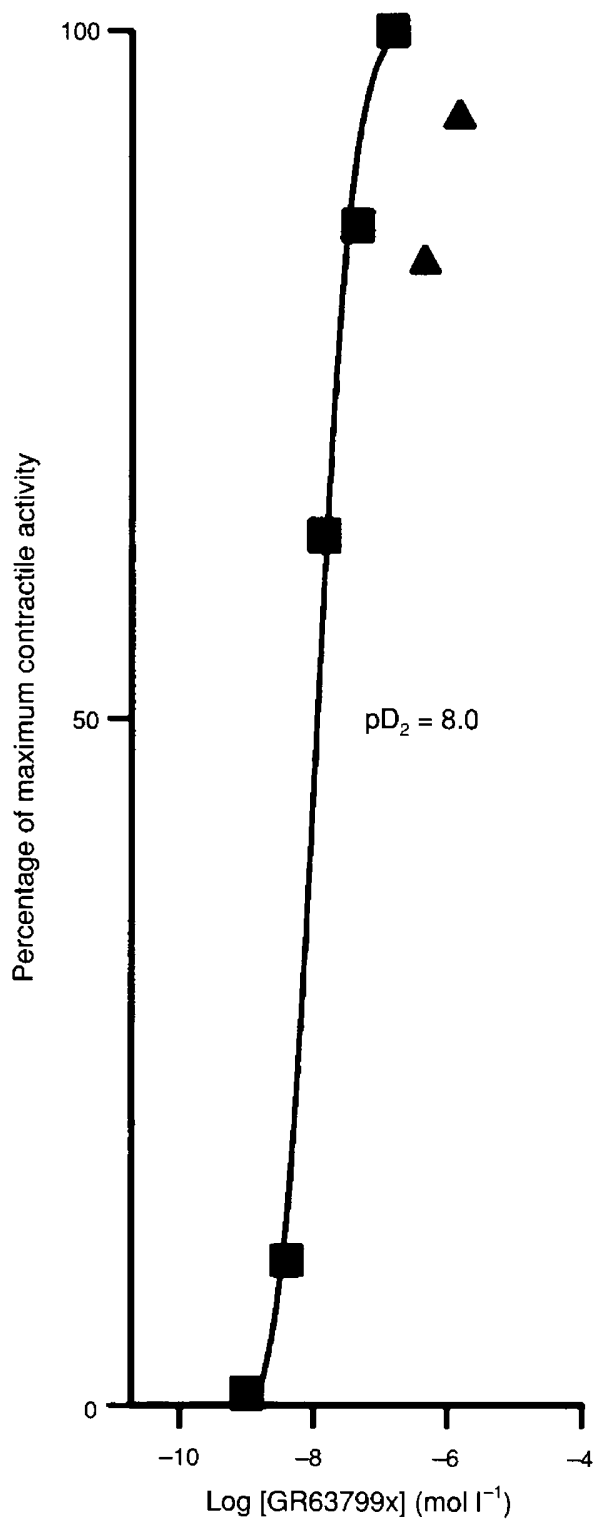

Fig. 3. Concentration-effect curve to the EP receptor agonist GR63299x resulting from the data in Fig. 2. The last two collections in this experiment $(\boldsymbol{\Delta})$ produced activities that were lower than the maximum, and were not therefore included in the determination of the $p \mathrm{D}_{2}$ value.

\section{Results}

When incubated under the conditions described, $80 \%$ of the myometrial strips used developed high frequency $\left(1-5 \mathrm{~min}^{-1}\right)$, low amplitude (about $10 \mathrm{mN}$ ) spontaneous contractions. The remainder were quiescent. Lack of development of spontaneous contractility was not correlated with failure to respond to potassium chloride challenge or to prostanoid addition. Of those tissues that developed spontaneous contractions, $15 \%$ also developed low frequency $\left(0.3-0.5 \mathrm{~h}^{-1}\right)$, high amplitude (about $20 \mathrm{mN}$ ) contractions.

Concentration-dependent increases in the contractile activity of the sheep myometrium in vitro were produced by the prostanoids $\mathrm{PGD}_{2}, \mathrm{PGE}_{2}, \mathrm{PGF}_{2 \alpha^{\prime}}$ iloprost, 17-phenyltrinor
$\mathrm{PGE}_{2}$, sulprostone, misoprostol, GR63799x, cloprostenol and U46619, and also by oxytocin and carbachol. Conversely, the prostanoids BW245c, ZK110841, AH13205, and cicaprost were not capable of increasing contractile activity at concentrations up to $30,10,80$ and $0.05 \mu \mathrm{mol} \mathrm{l}^{-1}$, respectively.

Figure 1 shows the complete tension recording from one of the experiments investigating the effects of an excitatory agonist (GR63799x). The concentration-effect portion of this experiment is shown in Fig. 2 and the resulting concentrationeffect curve in Fig. 3. Table 2 shows the potencies of all the agonists tested that had excitatory effects.

There were no differences in the $p \mathrm{D}_{2}$ values obtained for 17-phenyltrinor $\mathrm{PGE}_{2}$ and GR63799x in the presence or in the absence of the $\mathrm{EP}_{1}$ antagonist $\mathrm{AH} 6809$ (Coleman et al., 1985) at $40 \mu \mathrm{mol} \mathrm{l}^{-1}(n=4)$. Conversely, the concentration-effect curves for iloprost were displaced so far to the right in the presence of AH6809 that reliable $p \mathrm{D}_{2}$ values could not be determined with the concentrations of the agonist available.

The selective DP receptor antagonist BW A868c (Giles et al., 1989) at $1 \mu \mathrm{mol} l^{-1}$ had no effect on responses to $\mathrm{PGD}_{2}$. The selective TP receptor antagonist, L670596 (Ford-Hutchinson et al., 1989) shifted the concentration-effect curves for U46619 to the right. Control $p \mathrm{D}_{2}$ values were $6.34 \pm 0.29$; those in the presence of $\mathrm{L} 670596$ were $5.79 \pm 0.2$, giving a mean $p \mathrm{~K}_{\mathrm{B}}$ for L670596 of 8.4.

The $\beta$-adrenoceptor agonist isoprenaline and the Ca-channel antagonist D600 caused concentration-dependent inhibition of $\mathrm{KCl}$ - and cloprostenol-induced activity. Figure 4a shows the decline in cloprostenol-induced activity with time and Fig. $4 \mathrm{~b}$ shows the decline in cloprostenol-induced activity in a matched strip that was treated with isoprenaline. The response to isoprenaline was biphasic, showing excitation at very high concentrations, whereas the response to D600 (not shown) was monophasic. The $p \mathrm{D}_{2}$ value for isoprenaline was $8.8 \pm 0.8$ $(n=4)$ and for D600 it was $6.3 \pm 0.3(n=3)$. None of the prostanoids BW 245c (up to $30 \mu \mathrm{mol} \mathrm{l}{ }^{-1}$ ), ZKI10841 (up to

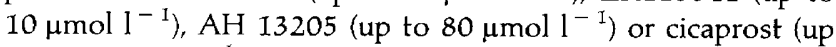
to $0.14 \mu \mathrm{mol}^{-1}$ ) produced detectable inhibition of activity.

\section{Discussion}

The similar and relatively high potencies with which the natural prostanoids $\mathrm{PGD}_{2}, \mathrm{PGE}_{2}$ and $\mathrm{PGF}_{2 \alpha}$ caused contractions of the myometrium of nonpregnant ewes in vitro suggest that each agent produces its effect by action at its own receptor (Coleman et al., 1990): the DP, EP, and FP receptors, respectively. However, some evidence suggests that DP receptors are not present in sheep myometrium. First, DP receptors mediate predominantly inhibitory responses, for example, inhibition of smooth muscle contractions and platelet aggregation (Coleman et al., 1990), rather than excitation. Second, the contractile effects of $\mathrm{PGD}_{2}$ are not antagonised by the potent and selective DP receptor antagonist, BW A868c (Giles et al, 1989). Third, the selective DP receptor agonists, BW245c (Town et al., 1983) and ZK110841 (Thierauch et al., 1988) are ineffective. The contractile effects of $\mathrm{PGD}_{2}$ may be produced by action at EP, FP or TP receptors; however, its potency would be expected to be significantly less than those of $\mathrm{PGE}_{2}$, $\mathrm{PGF}_{2 a}$ or U46619, respectively (Coleman et al., 1990). This is 
Table 2. Effect of excitatory agonists on the contractility of the myometrium from nonpregnant ewes in vitro

\begin{tabular}{|c|c|c|c|c|}
\hline Class & Compound & $p \mathrm{D}_{2}$ & $\mathrm{SD}$ & $n$ \\
\hline \multirow[t]{3}{*}{ Natural prostanoid } & $\mathrm{PGD}_{2}$ & 6.87 & 0.31 & 7 \\
\hline & $\mathrm{PGE}_{2}$ & 6.67 & 0.26 & 14 \\
\hline & $\mathrm{PGF}_{2 a}$ & 6.90 & 0.46 & 10 \\
\hline \multirow[t]{5}{*}{ EP agonist } & 17-phenyltrinor $\mathrm{PGE}_{2}$ & 7.39 & 0.35 & 13 \\
\hline & GR $63799 x$ & 6.95 & 0.53 & 13 \\
\hline & Iloprost & 8.34 & 0.12 & 4 \\
\hline & Misoprostol & 8.31 & 0.4 & 4 \\
\hline & Sulprostone & 7.08 & 0.26 & 9 \\
\hline FP agonist & Cloprostenol & 6.78 & 0.68 & 10 \\
\hline TP agonist & U46619 & 6.21 & 0.39 & 8 \\
\hline \multirow[t]{2}{*}{ Non-prostanoid } & Carbachol & 6.68 & 0.36 & 8 \\
\hline & Oxytocin & 9.22 & 0.42 & 8 \\
\hline
\end{tabular}

(a)

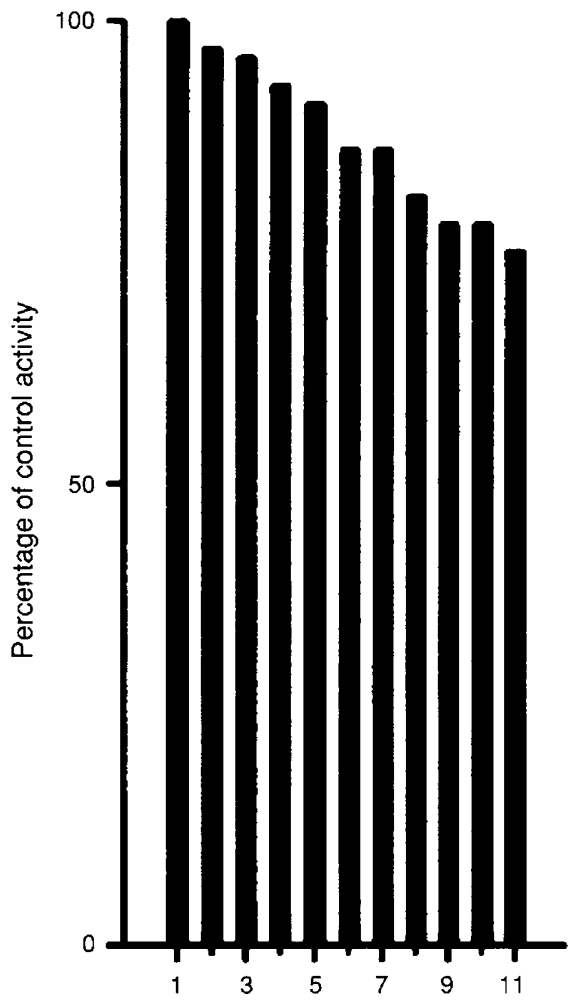

(b)

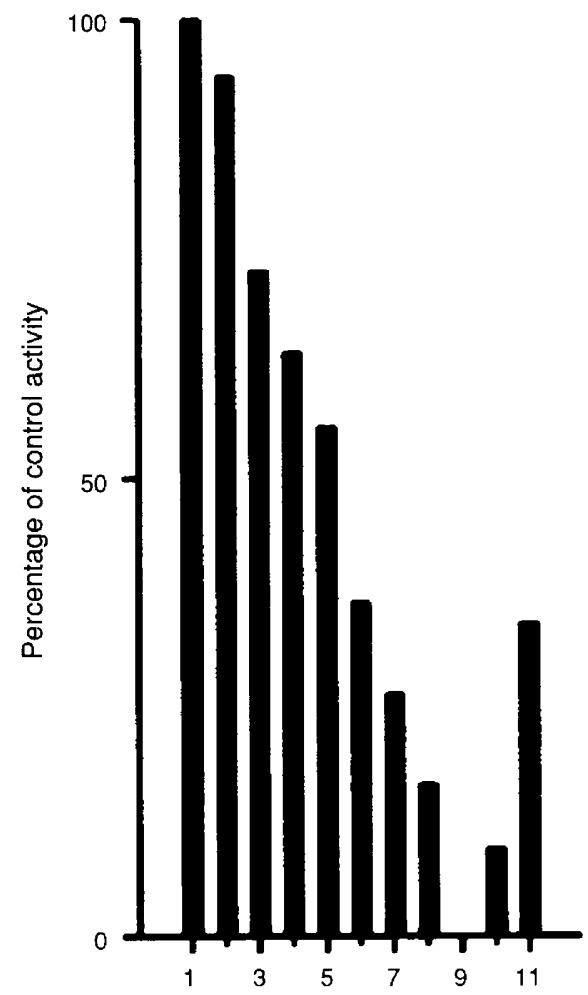

Fig. 4. Effect of (a) time and (b) the cumulative addition of isoprenaline, on contractile activity induced by cloprostenol of the sheep myometrium in vitro. Contractile activity was determined during successive 10 min collection periods, the first of which represented the control. In (b) cumulative concentrations of isoprenaline in the bath for collection $1-11$ were: $0,0.01,0.04,0.14$, $0.44,1.44,4.44,14.4,44.4,144.4,444 \mathrm{nmol} \mathrm{I}^{-1}$, respectively. Zero contractile activity was that

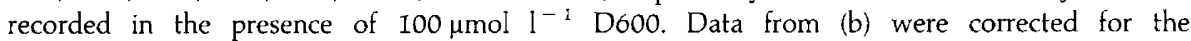
time-dependent changes in (a) to obtain a concentration-effect curve for isoprenaline.

not the case, and these results suggest that sheep myometrium contains an as yet uncharacterized excitatory receptor for $\mathrm{PGD}_{2}$ (Ito et al., 1990).

The presence of EP receptors in sheep myometrium is suggested by the values of the potencies of 17-phenyltrinor
PGE $_{2}$, GR63799x, iloprost, misoprostol and sulprostone in causing contraction of this tissue in vitro. However, there are four subtypes of $\mathrm{EP}$ receptors: $\mathrm{EP}_{1}$ and $\mathrm{EP}_{3}$ receptors mediate excitation of smooth muscle, whereas $\mathrm{EP}_{2}$ and $\mathrm{EP}_{4}$ receptors mediate inhibition (Coleman et al., 1990, 1994). 
The effectiveness and potency of sulprostone at provoking contractions of the sheep myometrium in vitro confirm the presence of excitatory EP receptors, since this compound has a high selectivity for $\mathrm{EP}_{1}$ and $\mathrm{EP}_{3}$ receptors (Coleman et al., 1990). GR63799x is a selective agonist for $\mathrm{EP}_{3}$ receptors; in $\mathrm{EP}_{3}$ receptor-dominated preparations, it was $10-50$ times more potent than $\mathrm{PGE}_{2}$; and in an $\mathrm{EP}_{1}$ dominated preparation, it was four times less potent (Bunce et al., 1990). In this study, GR63799x was equipotent with $\mathrm{PGE}_{2}$. This observation alone permits no definite conclusion about the site of action of GR63799x in the sheep myometrium. However, the observation that the selective $\mathrm{EP}_{1}$ antagonist, $\mathrm{AH} 6809$, had no effect on the response to GR63799x strongly indicates that if $\mathrm{EP}_{1}$ receptors are involved, they do not predominate. Thus, by default, the response to the agonist must be mediated mainly by $\mathrm{EP}_{3}$ receptors. Consequently, we conclude that the sheep myometrium in vitro expresses $\mathrm{EP}_{3}$ receptors linked to contraction. This conclusion is supported by the high contractile potency of misoprostol: a compound with mixed $\mathrm{EP}_{2}$ and $\mathrm{EP}_{3}$ activity (Coleman et al., 1988).

The failure of the selective $\mathrm{EP}_{2}$ agonist $\mathrm{AH} 13205$ (Nials et al., 1991) to display either excitatory or inhibitory actions on the sheep myometrium suggests that $\mathrm{EP}_{2}$ receptors are absent.

Iloprost has agonist activity at both $\mathrm{EP}_{1}$ and IP receptors (Coleman et al., 1990). Action at IP receptors would be expected to produce inhibition of smooth muscle contractility (Coleman et al., 1990). Therefore, the potent contractile activity of iloprost suggests an action at $\mathrm{EP}_{1}$ receptors. This is confirmed by the observation that iloprost was antagonised by $\mathrm{AH6809}$. It has been suggested that 17-phenyltrinor $\mathrm{PGE}_{2}$ is a selective $\mathrm{EP}_{1}$ receptor agonist (Lawrence et al., 1989), although the evidence to support this is not compelling, so its potency on the sheep myometrium might be taken as confirmation of the presence of $E P_{I}$ receptors in this preparation. However, unlike that of iloprost, the action of 17-phenyltrinor $\mathrm{PGE}_{2}$ was not sensitive to $\mathrm{AH} 6809$, and therefore not mediated by $\mathrm{EP}_{1}$ receptors. This observation highlights the danger of relying solely on selective agonist potencies for receptor classification.

There is, unfortunately, no choice but to rely upon the equipotency of $\mathrm{PGF}_{2 a}$ and cloprostenol (Dukes et al., 1974), a selective FP receptor agonist (Coleman et al., 1990) to support the existence of FP receptors coupled to contraction in the sheep myometrium. Similar evidence using fluprostenol, an analogue of cloprostenol, has been used in the same way in human myometrium from both nonpregnant and term pregnant donors (Senior et al., 1992, 1993).

Cicaprost shows a high degree of selectivity for the IP receptor (Coleman et al., 1990). The fact that it was devoid of activity in our experiments suggests the absence of IP receptors in the sheep myometrium. This hypothesis is supported by the fact that we could detect no inhibitory action for iloprost, which is a potent IP receptor agonist (Coleman et al., 1990). However, Lye and Challis (1982) demonstrated inhibition of myometrial activity in vivo by both $\mathrm{PGI}_{2}$ and $\mathrm{PGI}_{2}$ methyl ester in nonpregnant ovariectomized ewes; this observation suggests a role for the IP receptor in myometrial inhibition. Perhaps the explanation for the discrepancy is methodological. Either the different hormonal environment of ovariectomized versus seasonally oestrous ewes induces IP receptors in the myometrium, or $\mathrm{PGl}_{2}$ acts indirectly to produce myometrial inhibition.
The activity of U46619, a stable synthetic thromboxane mimetic (Coleman et al., 1990), suggests the presence of TP receptors in the sheep myometrium. This hypothesis is supported by the effectiveness of the selective TP antagonist L670596 (Ford-Hutchinson et al., 1989) in blocking the responses to U46619. We determined a $p \mathrm{~K}_{\mathrm{B}}$ for $\mathrm{L} 670596$ of 8.4 in the sheep myometrium, whereas Ford-Hutchinson et al. (1989) report a value of 9.0 in the guinea-pig tracheal chain. This difference could be explained by action of U46619 at more than one type of receptor in the sheep myometrium, or by species variants of the TP receptor between sheep and guinea-pigs.

Our data are consistent with the hypothesis that the myometrium of the nonpregnant sheep contains all currently known excitatory prostanoid receptors: $\mathrm{EP}_{1}, \mathrm{EP}_{2}, \mathrm{FP}$ and $\mathrm{TP}$, but no inhibitor receptors. Failure to demonstrate inhibition by the prostanoids was not methodological, since a clear concentration-dependent inhibition was produced by the $\beta$-adrenoceptor agonist isoprenaline.

The human myometrium also contains all excitatory receptors, but in addition, it contains DP, $\mathrm{EP}_{2}$ and IP receptors (Senior $e$ t al., 1992, 1993). Guinea-pig and rat uteri, like that of the sheep, lack inhibitory receptors but, unlike the sheep uterus, the guinea-pig uterus also lacks FP receptors and the rat uterus lacks TP receptors (Coleman et al., 1990).

The pharmacological characterization of prostanoid receptors in the myometrium of the nonpregnant ewe performed in this study should help us to understand better the physiological role of prostanoids in reproductive processes in sheep.

The authors thank the management and staff of Hogeterp Meats and of Millgrove Packers for their assistance with collection of the uteri. They thank B. Kostolanska for performing some of the experiments and R. A. Coleman and P. K. Rangachari for comments on the manuscript. This study was supported by the Medical Research Council of Canada.

\section{References}

Bunce KT, Clayton NM, Coleman RA, Collington EW, Finch H, Humphray JM, Humphrey PPA, Reeves JJ, Sheldrick RLG and Stables R (1990) GR63799X a novel prostanoid with selectivity for $\mathrm{EP}_{3}$ receptors Advances in Prostaglandin. Thromboxane, and Leukotriene Research $21379-382$

Cheuk JMS, Hollingsworth M, Hughes SJ, Piper IT and Maresh MJA (1993) Inhibition of contractions of the isolated human myometrium by potassium channel openers American journal of Obstetrics and Gynecology 168 953-960

Coleman RA, Kennedy I and Sheldrick RLG (1985) AH6809, a prostanoid EP 1 receptor blocking drug British Journal of Pharmacology $85273 \mathrm{P}$

Coleman, RA, Humphray JM, Sheldrick RLG and White BP (1988) Gastric anti-secretory prostanoids: action at different prostanoid receptors British Journal of Pharmacology $95724 \mathrm{P}$

Coleman RA, Kennedy I, Humphrey PPA, Bunce K and Lumley P (1990) Comprehensive medicinal chemistry: The rational design, mechanistic study and therapeutic application of chemical compounds Membranes and Receptors Vol 3 Eds C Hansch, PG Samm and JB Taylor. Pergamon Press, Oxford

Coleman RA, Grix SP, Head SA, Louttit JB, Mallett A and Sheldrick RLG (1994) A novel inhibitory prostanoid receptor in piglet saphenous vein Prostaglandins 47 15I-168

Crankshaw DJ (1990) Myometrial contractility in vitro; its role in an understanding of the mechanisms controlling uterine activity. In Uterine Contractility, Mechanisms of Control pp 85-101 Ed. RE Garfield. Norwell, Massachusetts 
Curry SH, Brown EA, Kuck H and Cassin S (1982) Preparation and stability of indomethacin solutions Canadian Journal of Physiology and Pharmacology 60 988-992

Dukes M, Russel W and Walpole AL (1974) Potent luteolytic agents related to prostaglandin $\mathrm{F}_{20}$ Nature (London) 250 330-331

Dyal R and Crankshaw DI (1988) The effects of some synthetic prostanoids on the contractility of the human lower uterine segment in vitro American Journal of Obstetrics and Gynecology 158 281-285

Ford-Hutchinson AW, Girard Y, Lord A, Jones TR, Cirino M, Evans JF, Gillad J, Hamel P, Leveillé C, Masson P and Young R (1989) The pharmacology of L-670,596, a potent and selective thromboxane/prostaglandin endoperoxide receptor antagonist Canadian Journal of Physiology and Pharmacology 67 989-993

Giles H, Leff P, Bolofo ML, Kelly MG and Robertson AD (1989) The classification of prostaglandin DP-receptor in platelets and vasculature using BW A $868 \mathrm{C}$, a novel, selective and potent competitive antagonist British Journal of Pharmacology 96 291-300

Ito S, Negishi M, Sugama K, Okuda-Ashitaka E and Hayaishi $O(1990)$ Signal transduction coupled to prostaglandin $\mathrm{D}_{2}$ Advances in Prostaglandin, Thromboxane, and Leukotriene Research 21 371-374

Lawrence RA, Jones RL and Wilson NH (1989) Relaxant potencies of prostaglandin $E_{2}$ analogues on rabbit jugular vein British Journal of Pharmacology 98 $796 \mathrm{P}$

Lye SJ and Challis JRG (1982) Inhibition by PGI-2 of myometrial activity in vivo in non-pregnant ovariectomized sheep Journal of Reproduction and Fertility $66 \quad 311-315$
Nials AT, Coleman RA, Hartley D and Sheldrick RLG (1991) AH13205 - a novel selective prostanoid $\mathrm{EP}_{2}$ agonist British Journal of Pharmacology 102 24P

Novy MJ and Liggins GC (1980) Role of prostaglandins, prostacyclin, and thromboxanes in the physiologic control of the uterus and in parturition Seminars in Perinatology 4 45-66

Olson DM, Lye SJ and Challis JRG (1986) Prostaglandin concentrations in ovine maternal and fetal tissues at late gestation Pediatric Research 20 83-86

Senior J, Marshall K, Sangha R, Baxter GS and Clayton JK (1991) In vitro characterization of prostanoid EP-receptors in the non-pregnant human myometrium British journal of Pharmacology 102 747-753

Senior J, Sangha R, Baxter GS, Marshall K and Clayton JK (1992) In vitro characterization of prostanoid FP-, DP-, IP- and TP-receptors on the non-pregnant human myometrium British Journal of Pharmacology 107 215-221

Senior J, Marshall K, Sangha R, and Clayton JK (1993) In vitro characterization of prostanoid receptors on human myometrium at term pregnancy British Journal of Pharmacology 108 501-506

Thierauch K-H, Stuzebecher C-St and Schillinger E (1988) Stable $9 \beta$ - or $11 \alpha-$ halogen-15-cyclohexyl-prostaglandins with high affinity to the $\mathrm{PGD}_{2^{-}}$ receptor Prostaglandins 35 855-868

Town M-H, Casals-Stenzel J and Schillinger E (1983) Pharmacological and cardiovascular properties of a hydantoin derivative, BW $245 \mathrm{C}$, with high affinity and selectivity for $\mathrm{PGD}_{2}$ receptors Prostaglandins 25 13-28

Wainman BC, Burcea I and Crankshaw DJ (1988) The effects of prostanoids on estrogen-dominated rat myometrial longitudinal muscle Biology of Reproduction $39221-228$ 